\title{
Comparative perianal fistula closure rates following autologous adipose tissue- derived stem cell transplantation or treatment with anti-tumor necrosis factor agents after seton placement in patients with Crohn's disease: a retrospective observational study
}

Min Young Park', Yong Sik Yoon ${ }^{1 *}$, Jong Lyul Lee', Sang Hyoung Park ${ }^{2}$, Byong Duk Ye ${ }^{2}$, Suk-Kyun Yang ${ }^{2}$ and Chang Sik Yu ${ }^{1}$

\begin{abstract}
Background: Perianal fistula is one of the most common complications in Crohn's disease, and various medical and surgical treatments are being tried. The aim of this study was to compare the perianal fistula closure rates following treatment with anti-tumor necrosis factor (TNF) agents or autologous adipose tissue-derived stem cell (auto-ASC) transplantation with Crohn's disease (CD).
\end{abstract}

Methods: CD patients who underwent seton placement for perianal fistula from January 2015 to December 2019 at a tertiary referral center were retrospectively reviewed. Patients were divided into two groups, one that received sequential treatments with anti-TNF agents (anti-TNF group) and the other that underwent auto-ASC transplantation (stem cell group). Clinical variables and fistula closure rates were compared in the two groups.

Results: Of the 69 patients analyzed, 39 were treated with anti-TNF agents and 30 underwent auto-ASC transplantation. Compared with the stem cell group, patients in the anti-TNF group were older $(p=0.028)$, were more frequently male $(p=0.019)$, had fistulas with more penetrating behavior $(p=0.002)$, had undergone surgery more frequently $(p=0.010)$, and had a shorter interval from seton placement to intended treatment $(p<0.001)$. During a median follow-up of 46 months (range, 30-52.5 months), fistula closure rates were significantly faster ( $83.3 \%$ vs. $23.1 \%, p<0.001)$, and the mean interval from seton placement to fistula closure significantly shorter (14 vs. 37 months, $p<0.001)$ in the stem cell than in the anti-TNF group. Three patients experienced fistula recurrence, all in

\footnotetext{
*Correspondence: yoonys@amc.seoul.kr

'Department of Colon and Rectal Surgery, Asan Medical Center, University of College of Medicine, 88, Olympic-ro 43-gil, Songpa-gu, Seoul 05505, Republic of Korea

Full list of author information is available at the end of the article
}

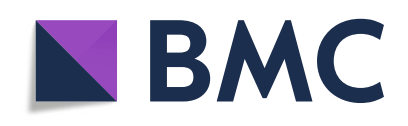

(- The Author(s). 2021 Open Access This article is licensed under a Creative Commons Attribution 4.0 International License, which permits use, sharing, adaptation, distribution and reproduction in any medium or format, as long as you give appropriate credit to the original author(s) and the source, provide a link to the Creative Commons licence, and indicate if changes were made. The images or other third party material in this article are included in the article's Creative Commons licence, unless indicated otherwise in a credit line to the material. If material is not included in the article's Creative Commons licence and your intended use is not permitted by statutory regulation or exceeds the permitted use, you will need to obtain permission directly from the copyright holder. To view a copy of this licence, visit http://creativecommons.org/licenses/by/4.0/ The Creative Commons Public Domain Dedication waiver (http://creativecommons.org/publicdomain/zero/1.0/) applies to the data made available in this article, unless otherwise stated in a credit line to the data. 
the stem cell group.

Conclusions: Medical treatment using anti-TNF agents and auto-ASC transplantation are feasible treatment options after seton placement for Crohn's perianal fistula. However, the closure rate was significantly faster and the time to closure significantly shorter in patients who underwent auto-ASC transplantation than medical treatment.

Trial registration: This study was retrospectively registered and approved by the Institutional Review Board of Asan Medical Center, number 2020-1059.

Keywords: Adipose tissue-derived stem cell, ASC, Biologics, Crohn's disease, Fistula

\section{background}

Crohn's disease is a chronic relapsing systemic inflammatory disease of unknown origin which interest the whole intestine, most frequently affecting the distal ileum $[1,2]$. This transmural inflammation disrupts the integrity of the intestinal mucosa, favoring the development of abscesses and fistulas. When fistulas were formed, they can make tracks between intestines or between the intestine and other organs such as the bladder, vagina, adjacent tissue or the skin [3]. A perianal fistula is an abnormal communication between the rectum or anal canal and the external perianal or ischioanal skin [1]. Perianal fistula is one of the most common complications in Crohn's disease (CD), with an estimated lifetime risk in western patients of $14 \%$ to $38 \%$ [4]. The incidence of perianal complications is higher in East Asian than in western patients, ranging from 30.3\% to $58.8 \%$ [5]. Moreover, the incidence of CD is increasing in Asia, with $43 \%$ of CD patients in South Korea having perianal fistula [6].

Medical treatment for $\mathrm{CD}$ is mainly focused on the control of bowel inflammation, not fistula. Antibiotics are commonly used as a first-line therapy for fistula treatment, but have not been proven to be effective in treating Crohn's perianal fistula (CPF) [7]. A metaanalysis of five studies found a response in $54 \%$ of patients treated with azathioprine or 6-mercaptopurine, but this meta-analysis was limited in that the literature reviewed was not a well-designed prospective clinical study and that response assessments to fistulas were made on different criteria with complete closure or reduced discharge as secondary endpoints [8]. Nowadays, biological agents such as anti-tumor necrosis factor (TNF)- $\alpha$ are increasingly being used to treat Crohn fistula $[9,10]$. Because CD is associated with a T-cell mediated response, and the hallmark of pathogenesis is transmural inflammation, which is facilitated by increased proinflammatory cytokines, interferon- $\gamma$ and interleukin-12, as well as TNF- $\alpha$ [11-14]. Previous studies reported that TNF- $\alpha$ is increased in the stool of patients with active $\mathrm{CD}$ compared to controls $[15,16]$. Anti-TNF antibodies are thought to neutralize of TNF$\alpha$, reverse signaling, apoptosis, and cytotoxicity [17] and have a predilection and efficiency for distribution into inflamed tissue [18]. Anti-TNF therapies with an Fc region (infliximab and adalimumab) are also able to induce antibody-dependent cell mediated cytotoxicity and complement-dependent cytotoxicity [18]. In the ACCE NT II trial, the closure rate of fistula was $63 \%$ at week 14 but decreased to $36 \%$ at week 54 [10]. Overall, the currently available treatments for CPF are not satisfactory as they do not achieve complete closure and reduction of recurrence. Although anti-TNF agents are an effective option for treatment of Crohn's perianal fistula [19], treatment with biologic agents alone does not result in high cure rates $[20,21]$. Rather, effective treatment of CPF requires a combination of biologic agents and surgery, with closure rates of $50-82 \%$ [22].

Given the problem of Crohn's fistula and the unmet medical needs, attention has been focused on stem cell therapy. Autologous or allogenic adipose tissue-derived stem cells (ASCs) may be safe and effective for the treatment of CPF. In a previous study, ASC transplantation resulted in closure of recto-vaginal fistula in patients with perianal Crohn's disease without any adverse events related to the treatment and recurrence [23, 24]. In addition, the other study reported higher quality of life scores and closure rates of ASCs than controls [25]. Autologous ASCs (auto-ASCs), which are commercially available in South Korea, have shown favorable result with $80.8 \%$ of 2 -year closure rate [26]. In clinical practice, many patients with CPF initially undergo seton placement to control perianal inflammation and to maintain immunosuppressive medications such as azathioprine, mercaptopurine and methotrexate which reduce abnormal immune reactions. Multi-disciplinary teams (MDTs) can then decide on further treatment options, consisting of either biologic agents or surgery including auto-ASC transplantation.

Beyond conventional medical treatments such as immunosuppressive medications, the development of biologics that target specific mechanisms of the disease has resulted in more remission in Crohn's disease patients [27]. Therefore, in Korea, where Crohn's disease is treated according to step-up approach, biologics are administered as the last step [28]. The use of biologics in 
South Korea has recently increased due to the expansion of medical treatment [29-31]. Moreover, the number of patients who have undergone perianal surgery during treatment with biologics has increased because of the high proportion of Korean CD patients with perianal fistulas $[6,29]$. Currently, the types of biologics used in Korea include anti-TNF agents, anti-interleukin 12/23 agents and anti- $\alpha 4 \beta 7$ integrin agents. Among them, antiTNF agents (infliximab and adalimumab) are mostly used. This study therefore compared outcomes in patients with CPF who underwent auto-ASC transplantation or were treated with anti-TNF agents.

\section{Methods}

\section{Patients and clinical variables}

Data were retrospectively reviewed in CPF patients who underwent seton placement from January 2015 to December 2019 at Asan Medical Center, Seoul, South Korea. CD was diagnosed by gastroenterologists based on clinical, endoscopic, radiological, and histopathologic criteria according to the diagnostic guidelines for $\mathrm{CD}$ in Korea [32]. There is no single gold standard for the diagnosis of $C D$ and typical endoscopic findings of $C D$ are non-continuous distribution of longitudinal ulcers, cobblestone mucosal appearance, and aphthous ulcerations arranged in a longitudinal fashion. The evaluation of small bowel with small bowel follow-through is recommended for suspected CD to establish diagnosis and to determine the extent and location of disease. Focal and patchy chronic inflammation, focal crypt irregularity, and non-caseating granulomas are usual microscopic features of CD. Patients who underwent examination under anesthesia, those without a detected fistula tract, patients with insufficient medical records, and those lost to follow-up were excluded. Patients were divided into an anti-TNF group and a stem cell group. The anti-TNF group included patients who received anti-TNF agent treatment for any purpose after seton drainage for perianal fistula. The stem cell group included patients who underwent auto-ASC transplantation after seton drainage for perianal fistula without receiving anti-TNF agents. The anti-TNF group therefore included patients who received at least one injection or infusion of antiTNF agents within 3 months before or after surgery for treatment of perianal fistula, whereas the stem cell group excluded patients who received anti-TNF agents within 3 months before or after surgery for treatment of perianal fistula. Patients' characteristics, including age, gender, smoking, and subclass of the Montreal classification [33], were compared. The Montreal classification describes the age of onset, extent and behavior of $C D$ in more detail (Table 1). Fistula evaluation included fistula type (simple vs. complex, single vs. multiple), perioperative $\mathrm{CD}$ medication (immunomodulators or steroids)
Table 1 Montreal classification

\begin{tabular}{ll}
\hline Classification & Description \\
\hline Age of onset (A) & \\
A1 & 16 years old or younger \\
A2 & $17-40$ years old \\
A3 & Over 40 years old \\
Location $(L)$ & \\
L1 & Terminal ileum \\
L2 & Colon \\
L3 & Ileocolon \\
L4 & Upper gastrointestinal \\
Behavior (B) & \\
B1 & Non-stricturing, non-penetrating \\
B2 & Stricturing \\
B3 & Penetrating \\
\hline
\end{tabular}

without anti-TNF agents, presence of proctitis or stricture, and presence of perianal abscess. Anti-TNF agents used in this study were infliximab (Remicade ${ }^{\bullet}$, Janssen Biotech, Inc., Horsham, PA, USA) and adalimumab (Humira ${ }^{\circ}$, AbbVie, Inc., North Chicago, IL, USA). AutoASC used in this study was Cupistem (Anterogen Co., Ltd, Seoul, South Korea). The study protocol was approved by the Institutional Review Board of Asan Medical Center (No. 2020-1059).

\section{Fistula types}

Fistulas were classified according to Park's classification criteria [34]. Based on the Park's classification, fistulas are categorized based on their position relative to the external sphincter (Figure 1). Fistulas were defined as intersphincteric when the tract penetrated the internal sphincter and coursed through the intersphincteric space to the perianal skin. Fistulas were defined as transsphincteric when the tract penetrated both the internal and external sphincters. Fistulas were defined as suprasphincteric when they crossed the internal sphincter and initially spread upwards to the intersphincteric space and then downwards, crossing the levator ani muscle before reaching the perianal skin. Fistulas were defined as extra-sphincteric when they originated from the rectal wall and coursed down through the levator ani muscle lateral to the external sphincter to reach the perianal skin, but did not penetrate the anal sphincter complex.

\section{Surgical procedures, anti-TNF agents, and postoperative management}

Seton placement: Under general anesthesia, the patient was placed in the prone jackknife position. The fistula tract was probed from the external openings and $\mathrm{cu}$ retted, and the surrounding infected tissues were 


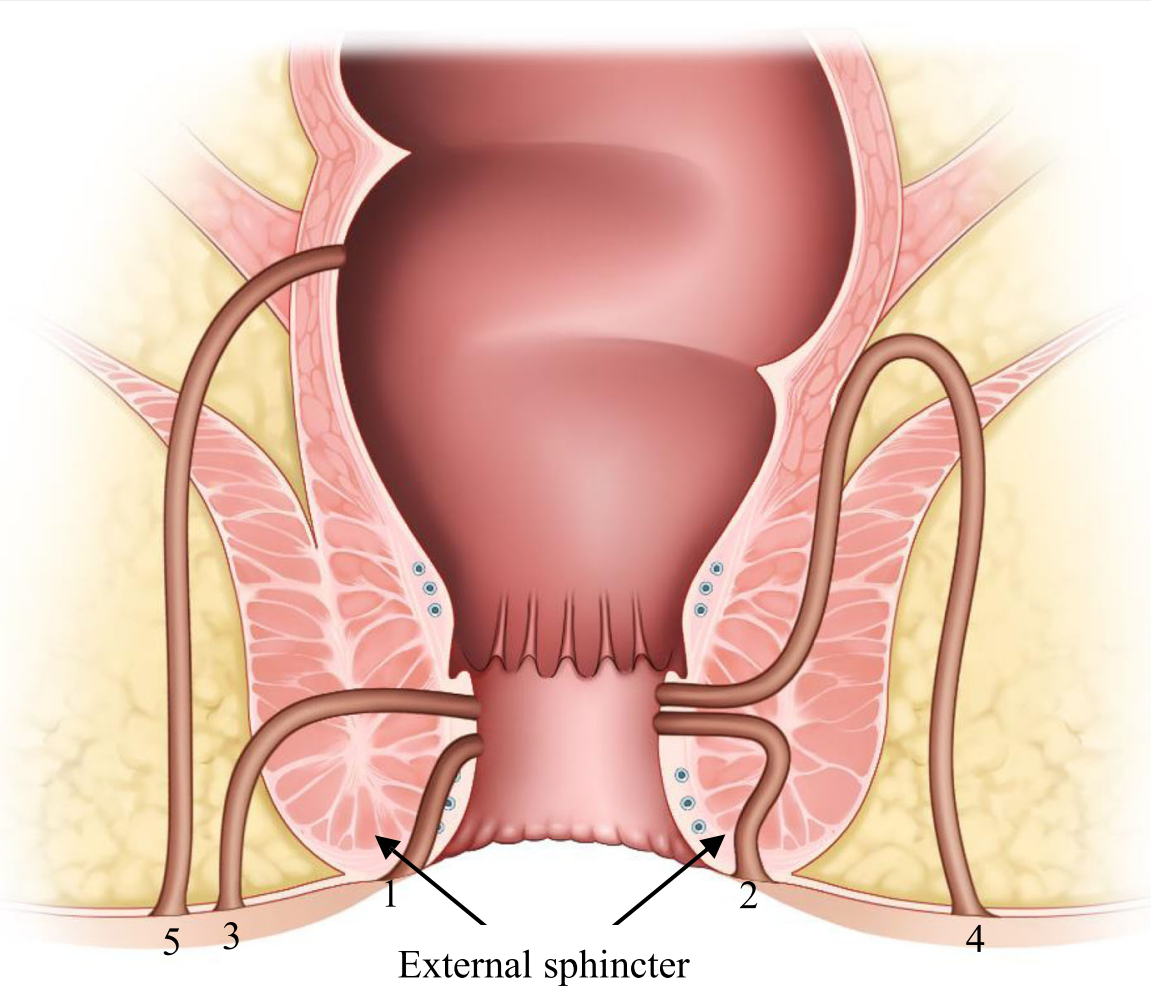

Fig. 1 The Park's classification of perianal fistulas. (1) Superficial, (2) Inter-sphincteric, (3) Trans-sphincteric, (4) Supra-sphincteric and (5) Extra-sphincteric

removed. A transsphincteric seton was applied and tied loosely as a noncutting seton drain (Figure 2). The type of seton drain was dependent on the type of fistula tract, with vessel loops used most frequently.

Auto-ASC transplantation: All candidates for autoASC transplantation underwent seton placement to control inflammation around the CPF. The tract was curetted to remove inflamed and fibrotic surrounding tissue, which prevents stem cell penetration. The tract was cleaned with isotonic saline, and the previous seton was removed. The internal opening of the tract on the rectal or anal canal was closed by direct suture ligation using vicryl. Stem cells were injected into the submucosa around the internal opening and fistula tract, and the opened fistula tract was filled with a mixture of stem cells and fibrin glue (Figure 3).

Anti-TNF agents: Infliximab was administered 2 and 6 weeks after the first dose, and 8 weeks after the third dose. Infliximab was administered $5 \mathrm{mg} / \mathrm{kg}$, and after that, when the reaction fell, the dose was increased to $10 \mathrm{mg} / \mathrm{kg}$. Adalimumab was administered every 2 weeks after the first dose. Adalimumab was administered at different doses in adults and children. In adults, the first $160 \mathrm{mg}, 80 \mathrm{mg}$ at 2 weeks, $40 \mathrm{mg}$ at 4 weeks, and 40 mg every two weeks after that. In case of decreased response to adalimumab, it can be increased from every 2 weeks to every week. In children, it was different depending on the body weight. When the weight was less than $40 \mathrm{~kg}, 40 \mathrm{mg}$ was initially administered, followed by $20 \mathrm{mg}$ ever two weeks. In the case of $40 \mathrm{~kg}$ or more, $80 \mathrm{mg}$ was initially administered, followed by $40 \mathrm{mg}$ every two weeks $[35,36]$.

Postoperative management: Patients who underwent surgery were discharged home the next day and followed up at the outpatient clinic every 1 or 2 months. If there was no discharge or inflammation around the seton, seton removal was considered after discussion with the patient.

\section{Preparation of autologous ASCs}

The auto-ASCs were transplanted with at a dose of $3 \times 10^{7}$ cells $/ \mathrm{ml}$ (Cupistem ${ }^{\circ}$, Anterogen Co., Ltd, Seoul, South Korea). These auto-ASCs were isolated from each patient's subcutaneous fat tissue by lipo-aspiration. The lipo-aspirates were washed with phosphate buffered saline (PBS, Hyclone, Logan, UT, USA, http://www. hyclone.com) and digested in an equal volume of PBS containing $1 \%$ bovine serum albumin (BSA, Thermo Fisher Scientific, Penrose, AKL, NZ, https://www. thermofisher.com) and $0.025 \%$ collagenase type I (Thermo Fisher Scientific) for 80 minutes at $37^{\circ} \mathrm{C}$ with intermittent shaking. The stromal vascular fraction 
(a)

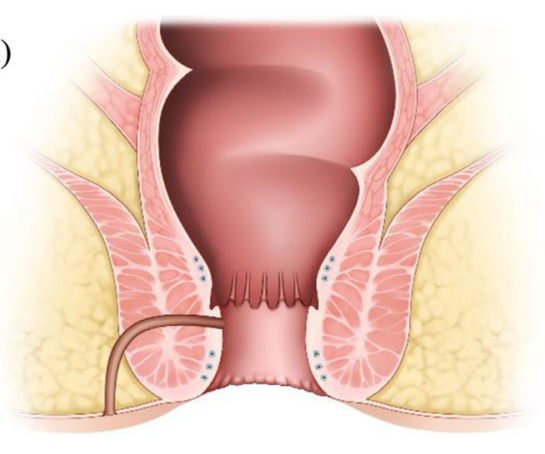

(c)

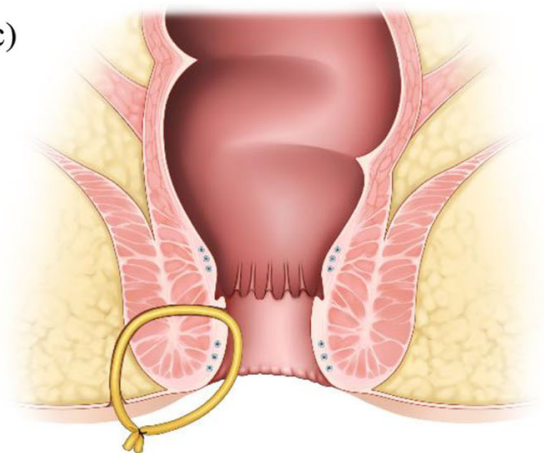

(b)

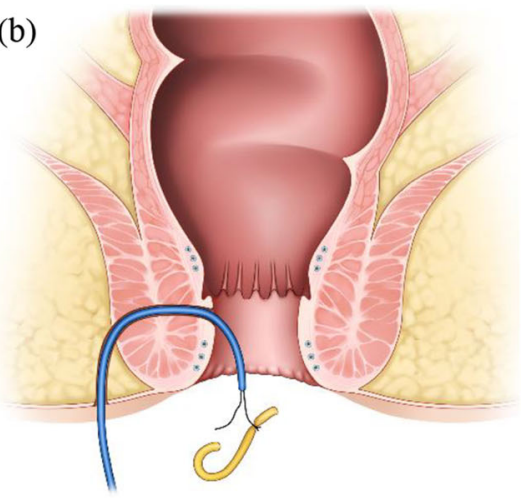

Fig. 2 The procedures of seton placement. (a) Check the fistula tract. (b) Probe the fistula tract and apply a transsphincteric seton. (c) Tie the seton loosely as a noncutting seton drain

isolated from the fat tissue was cultured in Dulbecco's modified Eagle's medium (DMEM, Hyclone) with 10\% fetal bovine serum (FBS, Hyclone) and $1 \mathrm{ng} / \mathrm{ml} \mathrm{hu-}$ man basic fibroblast growth factor (R\&D, Minneapolice, MN, USA, http://www.rndsystems.com) to obtain the required number of ASCs for injection. The cells were harvested by trypsinization, suspended in DMEM, and packaged in single-use vials. All manufacturing procedures were carried out according to the Good Manufacturing Practices authorized by the Ministry of Food and Drug Safety (former KFDA). Prior to release, auto-ASCs were tested for cell appearance, viability, cell surface marker, in addition to adventitious agents including mycoplasma and bacteria, fungi, viruses and endotoxin.

\section{Outcomes}

The primary outcome of the present study was a comparison of closure rates in the two groups. Closure of a fistula tract was defined as the absence of discharge, swelling, or pain. Recurrence was defined as a relapse of discharge and perianal symptoms, including pain and swelling, after closure of the fistulous tract without discharge.

\section{Statistics}

Categorical variables were expressed as numbers and percentages and compared by chi-square tests. Continuous variables were expressed as medians and interquartile range (IQR) or mean \pm standard deviation (SD) and compared by Student's t-tests. Cumulative rates of fistula closure and perianal fistula recurrence were calculated using the Kaplan-Meier method and compared using log-rank tests. All statistical analyses were performed using SPSS for Windows, ver. 25.0 (SPSS Inc., Chicago, IL, USA), with $\mathrm{p}<0.05$ considered statistically significant.

\section{Results}

Of the 333 perianal surgeries for CPF, 239 (71.8\%) involved seton placement; of the latter, 39 (16.3\%) patients were treated with anti-TNF agents (anti-TNF group) and $30(12.6 \%)$ underwent auto-ASC transplantation without anti-TNF agents (stem cell group). The 26 patients treated with anti-TNF agents and auto-ASC transplantation were excluded. Of the patients in the antiTNF group, three were administered these agents mainly for CPF closure.

The clinical characteristics of the anti-TNF and stem cell groups are summarized in Table 2 . Compared with 
(a)

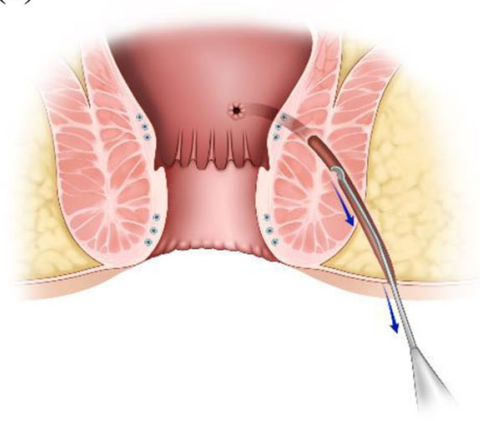

(c)

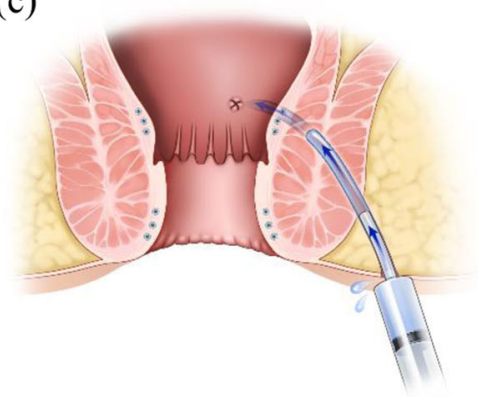

(b)

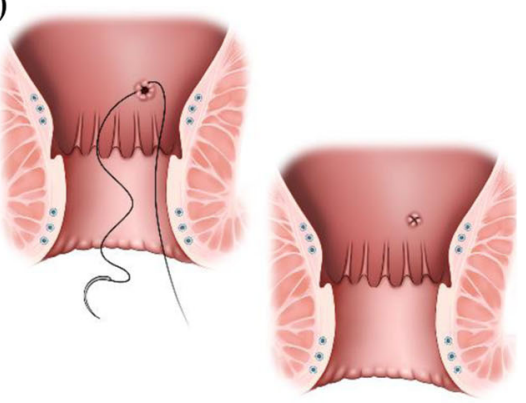

(d)

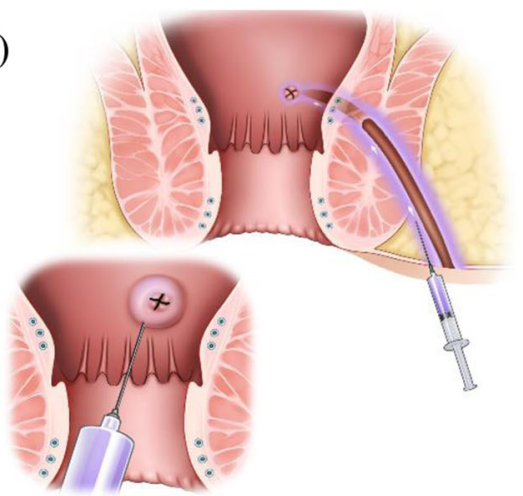

(e)

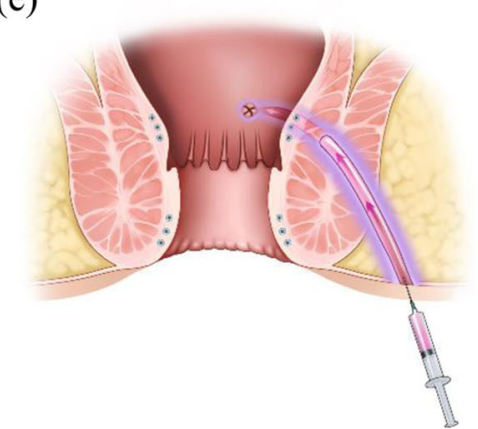

Fig. 3 The procedures of auto-ASC transplantation. (a) Probe the fistula tract and curette the tract. (b) Close the internal opening of the tract. (c) Irrigate the tract with isotonic saline. (d) Inject stem cells into the submucosa around the internal opening and fistula tract

the stem cell group, patients in the anti-TNF group were older $(\mathrm{p}=0.028)$, were more frequently male $(\mathrm{p}=0.019)$, and had fistulas with more penetrating behavior according to the Montreal classification $(\mathrm{p}=0.002)$. The mean albumin level tested before auto-ASC transplantation in the stem cell group or before seton placement in the anti-TNF group were statistically significantly higher in the stem cell group $(3.36 \pm 0.48$ vs. $4.05 \pm 0.42 \mathrm{~g} / \mathrm{dL}, \mathrm{p}<$ 0.001 ), but were above $3.0 \mathrm{~g} / \mathrm{dL}$ in both groups. In addition, the mean $\mathrm{C}$-reactive protein (CRP) level tested at the same time were significantly higher in the antiTNF group $(3.03 \pm 3.04$ vs. $0.56 \pm 0.74 \mathrm{mg} / \mathrm{dL}, \mathrm{p}<0.001)$. The anti-TNF group had undergone surgery more frequently $(\mathrm{p}=0.010)$, and had a shorter interval from seton treatment to intended treatment $(\mathrm{p}<0.001)$.

During a median follow-up of 46 months (IQR, 3052.5 months), closure rates were significantly higher in the stem cell group than in the anti-TNF group $(83.3 \%$ vs. $23.1 \%, p<0.001$; Figure 4 ). When adjusted the differences between the two groups, such as age, sex, behavior, albumin and CRP, closure rate was significantly faster in the stem cell group. Moreover, the mean time from seton placement to fistula closure was significantly shorter in the stem cell group than in the anti-TNF group ( 14 vs. 37 months, $\mathrm{p}<0.001$ ). Three patients experienced fistula recurrence, all in the stem cell group. The 
Table 2 Demographic and clinical characteristics of patients in the anti-TNF and stem cell groups

\begin{tabular}{|c|c|c|c|}
\hline & Anti-TNF $(n=39)$ & Stem cell $(n=30)$ & $p$-value \\
\hline Age, median (IQR) & $31.0(25-34)$ & $26.0(20-30.25)$ & 0.028 \\
\hline \multicolumn{4}{|l|}{ Sex } \\
\hline Male & $29(74.4 \%)$ & $14(46.7 \%)$ & \multirow[t]{2}{*}{0.019} \\
\hline Female & $10(25.6 \%)$ & $16(53.3 \%)$ & \\
\hline \multicolumn{4}{|l|}{ Montreal classification } \\
\hline \multicolumn{4}{|l|}{ Age at onset } \\
\hline $\mathrm{A} 1(\leq 16 \mathrm{yr})$ & 15 (38.5\%) & $6(20.0 \%)$ & \multirow[t]{3}{*}{0.098} \\
\hline A2 (17-40yr) & $24(61.5 \%)$ & $24(80.0 \%)$ & \\
\hline A3 ( $\geq 41 \mathrm{yr})$ & $0(0.0 \%)$ & $0(0.0 \%)$ & \\
\hline \multicolumn{4}{|l|}{ Location } \\
\hline L1 (lleum) & $4(10.3 \%)$ & $8(26.7 \%)$ & \multirow[t]{3}{*}{0.171} \\
\hline L2 (Colon) & $3(7.7 \%)$ & $3(10.0 \%)$ & \\
\hline L3 (Ileocolon) & $32(82.1 \%)$ & $19(63.3 \%)$ & \\
\hline \multicolumn{4}{|l|}{ Behavior } \\
\hline B1 (Non-stricturing, non-penetrating) & $12(30.8 \%)$ & $20(66.7 \%)$ & \multirow[t]{3}{*}{0.002} \\
\hline B2 (Stricturing) & $6(15.4 \%)$ & $6(20.0 \%)$ & \\
\hline B3 (Penetrating) & $21(53.8 \%)$ & $4(13.3 \%)$ & \\
\hline Albumin, mean $\pm \mathrm{SD}(\mathrm{g} / \mathrm{dL})$ & $3.36 \pm 0.48$ & $4.05 \pm 0.42$ & $<0.001$ \\
\hline $\mathrm{CRP}$, mean $\pm \mathrm{SD}(\mathrm{mg} / \mathrm{dL})$ & $3.03 \pm 3.04$ & $0.56 \pm 0.74$ & $<0.001$ \\
\hline \multicolumn{4}{|l|}{ Fistula type } \\
\hline Simple & $13(33.3 \%)$ & $6(20.0 \%)$ & \multirow[t]{2}{*}{0.219} \\
\hline Complex & $26(66.7 \%)$ & $24(80.0 \%)$ & \\
\hline Multiple fistula & $15(38.5 \%)$ & $13(43.3 \%)$ & 0.683 \\
\hline Proctitis & $19(48.7 \%)$ & $10(33.3 \%)$ & 0.199 \\
\hline Stricture & $1(2.6 \%)$ & $2(6.7 \%)$ & 0.407 \\
\hline Abscess & $18(46.2 \%)$ & $17(56.7 \%)$ & 0.387 \\
\hline \multicolumn{4}{|l|}{ Medical treatment } \\
\hline Immunomodulators & $16(41.0 \%)$ & $15(50.0 \%)$ & 0.458 \\
\hline Steroids & $2(5.2 \%)$ & $0(0.0 \%)$ & 0.208 \\
\hline \multicolumn{4}{|l|}{ Smoking } \\
\hline Current smoker & $4(10.3 \%)$ & $1(3.3 \%)$ & \multirow[t]{2}{*}{0.355} \\
\hline Ex-smoker & $8(20.5 \%)$ & $4(13.3 \%)$ & \\
\hline Previous fistula OP & $37(94.9 \%)$ & $30(100 \%)$ & 0.208 \\
\hline No. previous fistula OP, mean $\pm \mathrm{SD}$ (times) & $3.24 \pm 1.89$ & $2.17 \pm 1.29$ & 0.010 \\
\hline Interval from seton treatment to anti-TNF or stem cell therapy, mean \pm SD (months) & $1.03 \pm 0.93$ & $16.13 \pm 16.01$ & $<0.001$ \\
\hline Disease duration, mean $\pm \mathrm{SD}$ (years) & $9.37 \pm 6.13$ & $6.10 \pm 4.88$ & 0.018 \\
\hline
\end{tabular}

Results are presented as $\mathrm{n}(\%)$ unless otherwise indicated.

$I Q R$ Inter-quartile range, TNF tumor necrosis factor, SD Standard deviation, CRP C-reactive protein, OP operation

recurrence risk showed no significant difference between the two groups. The mean time to recurrence was 21 months (Table 3). Recurrent abscesses in two of the patients were controlled by antibiotics, whereas the abscess in the third patient resolved spontaneously without any treatment.

\section{Discussion}

Seton placement is the main type of perianal surgery used to control sepsis in patients with CPF. After CPF is controlled, it can be effectively treated with anti-TNF agents or auto-ASC transplantation. The present study compared these treatment modalities. Although auto- 


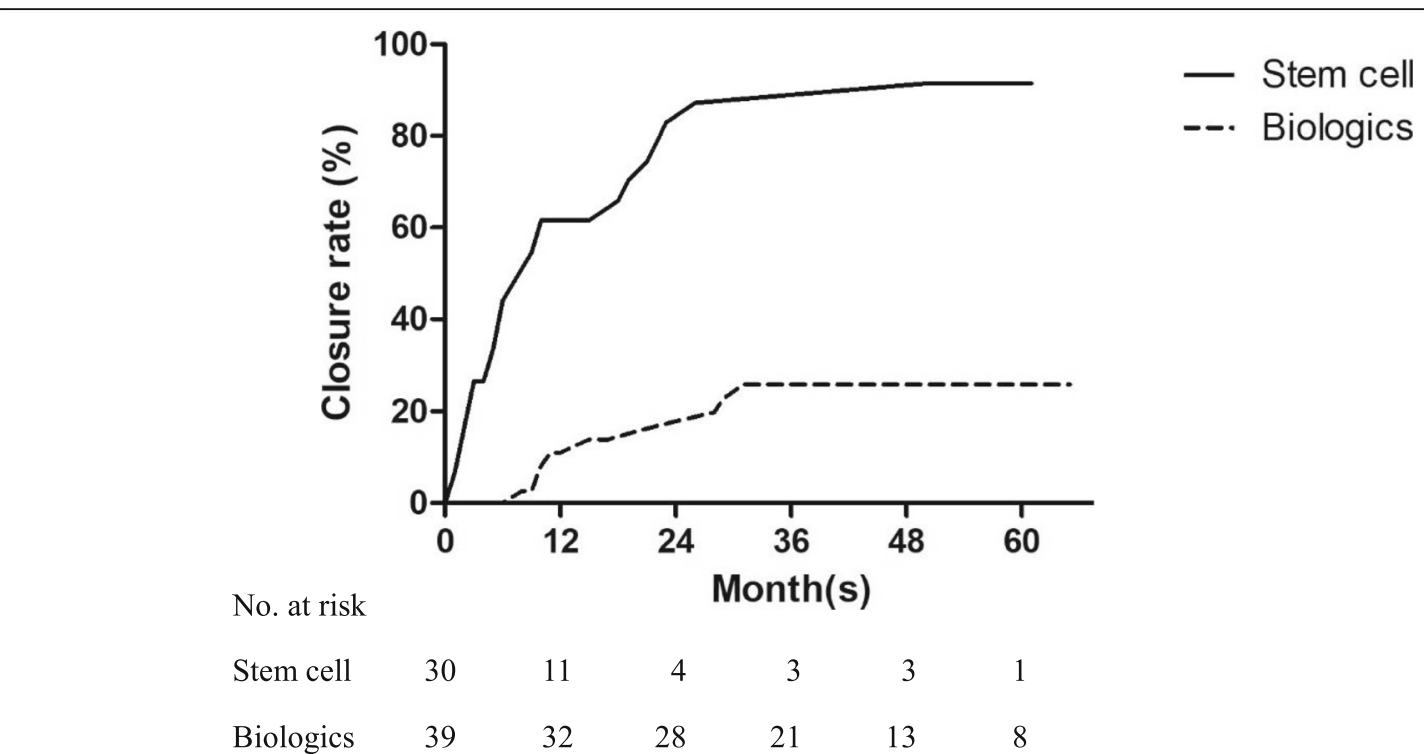

Fig. 4 Kaplan-Meier analysis of fistula closure rates over time in auto-ASC transplantation and anti-TNF agents. Closure rate in patients who underwent seton treatment followed by auto-ASC transplantation without biologics is higher than in patients who underwent seton treatment followed by treatment with anti-TNF agents

ASC transplantation is more invasive than medical treatment, it was found to be associated with a higher rate of and shorter time to fistula closure. Previous studies, however, have shown that combination treatment of biologics and surgery yielded excellent results $[37,38]$.

Medications, including antibiotics, immunosuppressants, and steroids, have shown limited efficacy in the treatment of $\mathrm{CPF}$, with high recurrence rates after cessation of treatment [39-41]. Infliximab is a wellestablished agent for the treatment of CD and CPF [42], although anti-TNF antibody treatment has improved outcomes in patients with $\mathrm{CD}$. A randomized trial showed that healing rates were significantly higher with infliximab ( 36-55\%) than with placebo ( 13-19\%) [10, $43]$. The combination of medication and surgery was more effective than either alone, with complete healing rates of $52 \%$ and $43 \%$, respectively [22]. Although antiTNF therapy was combined with seton placement in our anti-TNF group, the CPF closure rate was lower than in previous studies. One of the possible reasons for the low closure rate in our anti-TNF group was uncoordinated treatment by gastroenterologists and colorectal surgeons. Most of our study population was enrolled before 2019, when an MDT approach, which includes gastroenterologists, colorectal surgeons, radiologists, and pathologists, was introduced in our institution for the treatment of

Table 3 Rates of fistula closure and recurrence in patients in the anti-TNF and stem cell groups

\begin{tabular}{|c|c|c|c|c|c|c|c|}
\hline & $\begin{array}{l}\text { Anti-TNF } \\
(n=39)\end{array}$ & $\begin{array}{l}\text { Stem cell } \\
(n=30)\end{array}$ & $\begin{array}{l}\text { P by log-rank } \\
\text { test }\end{array}$ & $\begin{array}{l}\text { Unadjusted HR } \\
(95 \% \mathrm{Cl})\end{array}$ & $p$-value & $\begin{array}{l}\text { Adjusted HR } \\
(95 \% \mathrm{Cl})\end{array}$ & $p$-value \\
\hline Cumulative fistula closure, n (\%) & $9(23.1 \%)$ & $25(83.3 \%)$ & $<0.001$ & $8.17(3.72-17.94)$ & $<0.001$ & $3.15(1.22-8.13)$ & 0.018 \\
\hline 1 year & $4(10.3 \%)$ & $18(60.0 \%)$ & & & & & \\
\hline 2 year & $6(15.4 \%)$ & $23(76.7 \%)$ & & & & & \\
\hline 3 year & $9(23.1 \%)$ & $24(80.0 \%)$ & & & & & \\
\hline Closure time, mean $\pm \mathrm{SD}$ (months) & $36.7 \pm 19.2$ & $13.7 \pm 15.5$ & & & $<.001$ & & \\
\hline Cumulative fistula recurrence, $\mathrm{n}(\%)$ & $0(0 \%)$ & $3(10.0 \%)$ & 0.288 & $2.64(0.9-81.18)$ & 0.578 & & \\
\hline 1 year & - & $1(33.3 \%)$ & & & & & \\
\hline 2 year & - & $1(33.3 \%)$ & & & & & \\
\hline 3 year & - & $1(33.3 \%)$ & & & & & \\
\hline Recurrence time, mean $\pm \mathrm{SD}$ (months) & - & $21.33 \pm 13.05$ & - & & & & \\
\hline Follow up, mean $\pm S D$ (months) & $42.9 \pm 16.0$ & $39.2 \pm 18.6$ & & & 0.385 & & \\
\hline
\end{tabular}

Results are presented as $\mathrm{n}(\%)$ unless otherwise indicated.

TNF tumor necrosis factor, SD Standard deviation 
inflammatory bowel disease. This MDT approach, involving combinations of surgery and medications, has been shown to be effective in the treatment of CPF. Another reason for the low closure rate in our anti-TNF group may be the absence of a strict protocol for seton removal, which is subjectively determined by individual surgeons. In addition, anti-TNF agents used in the present study were mainly used for control of bowel inflammation rather than fistula closure. Thus, patients showed more aggressive behavior such as penetration according to the Montreal classification and higher CRP level in the anti-TNF group than in the stem cell group.

Stem cell transplantation of auto-ASCs for CPF has been shown to be safe and effective. For example, a phase I trial in five patients with $C D$ fistula resulted in $75 \%$ complete closure of the external opening [44]. A phase II study reported fistula closure in $56 \%$ of patients undergoing auto-ASC transplantation [25], and a phase III trial evaluating the efficacy of ASCs in complex fistulas resulted in fistula healing rates of approximately $40 \%$ at 6 months and $50 \%$ at 1 year [45]. Korean studies using auto-ASCs showed that the 1 and 2 year closure rates were $88 \%$ and $75 \%[26,46]$, respectively, comparable to our results. Since 2014, auto-ASC transplantation for CPF has been supported by the Korean government, with insurance covering the cost of this procedure (Cupistem ${ }^{\circ}$, Antrogen Co., Ltd) for patients with refractory or recurrent fistulas not responding to conventional treatment for more than 3 months, and for patients with complex fistulas where sphincter damage is expected after conventional surgery.

Rates of CPF recurrence have been reported to vary, from $17.8 \%$ for low-type fistulas to $55.5 \%$ for high-type fistulas after seton placement [47]. Another study reported recurrence rates of $42.8 \%$ in patients who received infliximab or underwent seton drainage alone, and $18.2 \%$ in patients receiving both seton placement and infliximab treatment [20]. The 1 and 2 year recurrence rates in patients who underwent auto-ASC transplantation were reported to be $11 \%$ and $16 \%$ [26, 46], respectively, consistent with the $10 \%$ rate in the present study. Given the significant rate of recurrence of CPF in patients receiving infliximab or underwent seton placement, stem cell transplantation would be a efficacious and safe alternative for refractory CPF in CD [48].

This study had important limitations due to its retrospective design, including strong selection bias and weighted grouping, with the course of disease being more aggressive in the anti-TNF than in the stem cell group. In addition, the number of patients was small and events were infrequent, precluding propensity score matching, multivariate analysis or adjustment. Actual fistula healing rate after treatment was not evaluated by imaging modalities, such as magnetic resonance imaging.
The low rate of closure in the anti-TNF group may have been affected by uncoordinated treatment before the institution of an MDT approach. Further studies in larger numbers of patients treated according to a defined MDT approach are needed to evaluate the actual effects of both treatment modalities.

\section{Conclusion}

In conclusion, medical treatment using anti-TNF agents and auto-ASC transplantation are feasible treatment options after seton placement for CPF. However, auto-ASC transplantation showed a higher closure rate than antiTNF treatment in the present study.

\section{Abbreviations}

Anti-TNF: Anti-tumor necrosis factor; CD: Crohn's disease; CPF: Crohn's perianal fistula; ASC: Adipose tissue-derived stem cell; MDT: Multi-disciplinary team; PBS: Phosphate buffered saline; DMEM: Dulbecco's modified Eagle's medium; FBS: Fetal bovine serum; IQR: Inter-quartile range

\section{Acknowledgements}

Authors would like to thank Inok Kim for reviewing the manuscript, providing information on preparation of Cupistem ${ }^{\bullet}$.

\section{Authors' contributions}

Chang Sik Yu guaranted the integrity of the study. Yong Sik Yoon conceived and designed the study. Yong Sik Yoon, Jong Lyul Lee and Min Young Park contributed to data acquisition. Min Young Park wrote manuscript and did statistical analysis. Yong Sik Yoon and Min Young Park edited manuscript. Yong Sik Yoon, Min Young Park, Sang Hyoung Park, Byong Duk Ye, and SukKyun Yang reviewed final manuscript. The authors read and approved the final manuscript.

\section{Funding}

No funding was obtained for this study.

\section{Availability of data and materials}

The datasets used and/or analysed during the current study are available from the corresponding author on reasonable request.

\section{Declarations}

Ethics approval and consent to participate

This retrospective study was performed following the ethical policies of the Asan Medical Center in Seoul, South Korea, and was approved by the Institutional Review Board of Asan Medical Center (No. 2020-1059). Informed consent was waived because of the retrospective observational nature of this study, involving previously collected data.

Consent for publication

Not applicable

\section{Competing interests}

The authors declare that they have no competing interests.

\section{Author details}

'Department of Colon and Rectal Surgery, Asan Medical Center, University of College of Medicine, 88, Olympic-ro 43-gil, Songpa-gu, Seoul 05505, Republic of Korea. ${ }^{2}$ Department of Gastroenterology, Asan Medical Center, University of Ulsan College of Medicine, Seoul, Republic of Korea. 
Received: 9 April 2021 Accepted: 23 June 2021

Published online: 13 July 2021

\section{References}

1. Steinhart AH, Panaccione R, Targownik L, Bressler B, Khanna R, Marshall JK, Afif W, Bernstein CN, Bitton A, Borgaonkar M: 0. Inflammatory bowel diseases 2019, 25(1):1-13.

2. Torres J, Mehandru S, Colombel J-F, Peyrin-Biroulet L. Crohn's disease. Lancet. 2017;389(10080):1741-55.

3. Taxonera C, Schwartz DA, García-Olmo D. Emerging treatments for complex perianal fistula in Crohn's disease. World J Gastroenterol: WJG. 2009;15(34): 4263.

4. Williams DR, Coller JA, Corman ML, Nugent FW, Veidenheimer MC. Anal complications in Crohn's disease. Dis Colon Rectum. 1981;24(1):22-4.

5. Im JP. Adalimumab or infliximab: which is better for perianal fistula in Crohn's disease? Intestinal Research. 2017;15(2):147.

6. Park SH, Kim Y-J, Rhee KH, Kim Y-H, Hong SN, Kim KH, et al. A 30-year trend analysis in the epidemiology of inflammatory bowel disease in the SongpaKangdong District of Seoul, Korea in 1986-2015. J Crohn's Colitis. 2019; 13(11):1410-7.

7. Present DH. Crohn's fistula: current concepts in management. Gastroenterology. 2003;124(6):1629-35.

8. Pearson DC, May GR, Fick GH, Sutherland LR. Azathioprine and 6mercaptopurine in Crohn disease: a meta-analysis. Ann Intern Med. 1995; 123(2):132-42.

9. Gecse KB, Bemelman W, Kamm MA, Stoker J, Khanna R, Ng SC, et al. A global consensus on the classification, diagnosis and multidisciplinary treatment of perianal fistulising Crohn's disease. Gut. 2014;63(9):1381-92.

10. Sands BE, Anderson FH, Bernstein CN, Chey WY, Feagan BG, Fedorak RN, et al. Infliximab maintenance therapy for fistulizing Crohn's disease. N Engl J Med. 2004;350(9):876-85.

11. Murch S, Braegger C, Walker-Smith J, MacDonald T. Location of tumour necrosis factor alpha by immunohistochemistry in chronic inflammatory bowel disease. Gut. 1993;34(12):1705-9.

12. Yapali S, Over Hamzaoglu H: Anti-TNF treatment in inflammatory bowel disease. Annals of gastroenterology 2007.

13. Mizoguchi E, Low D, Ezaki Y, Okada T. Recent updates on the basic mechanisms and pathogenesis of inflammatory bowel diseases in experimental animal models. Intestinal Res. 2020;18(2):151.

14. Ooi C, Hilmi I, Banerjee R, Chuah S, Ng S, Wei S, et al. Best practices on immunomodulators and biologic agents for ulcerative colitis and Crohn's disease in Asia. Intestinal Research. 2019;17(3):285-310.

15. Avdagic N, Babic N, Seremet M, Delic-Sarac M, Drace Z, Denjalic A, et al. Tumor necrosis factor-alpha serum level in assessment of disease activity in inflammatory bowel diseases. Med Glas (Zenica). 2013;10(2):211-6.

16. Braegger CP, Nicholls S, Murch S, MacDonald T, Stephens S. Tumour necrosis factor alpha in stool as a marker of intestinal inflammation. Lancet. 1992:339(8785):89-91.

17. Berns M, Hommes DW. Anti-TNF-a therapies for the treatment of Crohn's disease: the past, present and future. Expert Opin Investig Drugs. 2016;25(2): 129-43.

18. Mitoma H, Horiuchi T, Tsukamoto H, Ueda N. Molecular mechanisms of action of anti-TNF-a agents-comparison among therapeutic TNF-a antagonists. Cytokine. 2018;101:56-63.

19. de Groof EJ, Sahami S, Lucas C, Ponsioen CY, Bemelman WA, Buskens CJ. Treatment of perianal fistula in Crohn's disease: a systematic review and meta-analysis comparing seton drainage and anti-tumour necrosis factor treatment. Color Dis. 2016;18(7):667-75.

20. Sciaudone G, Di Stazio C, Limongelli P, Guadagni I, Pellino G, Riegler G, et al . Treatment of complex perianal fistulas in Crohn disease: infliximab, surgery or combined approach. Can J Surg. 2010:53(5):299.

21. Tozer P, Burling D, Gupta A, Phillips R, Hart A. Medical, surgical and radiological management of perianal Crohn's fistulas. Aliment Pharmacol Ther. 2011;33(1):5-22.

22. Yassin N, Askari A, Warusavitarne J, Faiz O, Athanasiou T, Phillips R, et al. Systematic review: the combined surgical and medical treatment of fistulising perianal Crohn's disease. Aliment Pharmacol Ther. 2014; 40(7):741-9.

23. Garcia-Olmo D, Garcia-Arranz M, Garcia LG, Cuellar ES, Blanco IF, Prianes LA, et al. Autologous stem cell transplantation for treatment of rectovaginal fistula in perianal Crohn's disease: a new cell-based therapy. Int J Color Dis. 2003;18(5):451-4.

24. Park K, Ryoo SB, Kim J, Kim T, Baik S, Kim H, et al. Allogeneic adiposederived stem cells for the treatment of perianal fistula in Crohn's disease: a pilot clinical trial. Color Dis. 2016;18(5):468-76.

25. Garcia-Olmo D, Herreros D, Pascual I, Pascual JA, Del-Valle E, Zorrilla J, et al. Expanded adipose-derived stem cells for the treatment of complex perianal fistula: a phase II clinical trial. Dis Colon Rectum. 2009;52(1):79-86.

26. Cho YB, Park KJ, Yoon SN, Song KH, Kim DS, Jung SH, et al. Long-term results of adipose-derived stem cell therapy for the treatment of Crohn's fistula. Stem Cells Transl Med. 2015;4(5):532-7.

27. Kim DH, Cheon JH. Pathogenesis of inflammatory bowel disease and recent advances in biologic therapies. Immune Network. 2017;17(1):25.

28. Lee K-M, Lee JM. Crohn's disease in Korea: past, present, and future. The Korean J Intern Med. 2014:29(5):558.

29. Ye BD, Yang S-K, Cho YK, Park SH, Yang D-H, Yoon SM, et al. Clinical features and long-term prognosis of Crohn's disease in Korea. Scand J Gastroenterol. 2010;45(10):1178-85.

30. Park SJ, Kim WH, Cheon JH. Clinical characteristics and treatment of inflammatory bowel disease: a comparison of eastern and Western perspectives. World J Gastroenterol: WJG. 2014;20(33):11525.

31. Jung YS, Han M, Kim WH, Park S, Cheon JH. Incidence and clinical outcomes of inflammatory bowel disease in South Korea, 2011-2014: a nationwide population-based study. Dig Dis Sci. 2017;62(8):2102-12.

32. Lennard-Jones J. Classification of inflammatory bowel disease. Scand J Gastroenterol. 1989;24(sup170):2-6.

33. Silverberg MS, Satsangi J, Ahmad T, Arnott ID, Bernstein CN, Brant SR, et al. Toward an integrated clinical, molecular and serological classification of inflammatory bowel disease: report of a working party of the 2005 Montreal world congress of gastroenterology. Can J Gastroenterol. 2005;19(Suppl A): 5A-36A.

34. Parks AG, Gordon PH, Hardcastle JD. A classification of fistula-in-ano. Br J Surg. 1976;63(1):1-12.

35. Hanauer SB, Sandborn WJ, Rutgeerts P, Fedorak RN, Lukas M, MacIntosh D, et al. Human anti-tumor necrosis factor monoclonal antibody (adalimumab) in Crohn's disease: the CLASSIC-I trial. Gastroenterology. 2006;130(2):323-33.

36. Sandborn WJ, Hanauer SB, Rutgeerts P, Fedorak RN, Lukas M, Maclntosh DG, et al. Adalimumab for maintenance treatment of Crohn's disease: results of the CLASSIC II trial. Gut. 2007;56(9):1232-9.

37. Bouguen G, Siproudhis L, Gizard E, Wallenhorst T, Billioud V, Bretagne JF, et al. Long-term outcome of perianal fistulizing Crohn's disease treated with infliximab. Clin Gastroenterol Hepatol. 2013;11(8):975-981. e974.

38. Gaertner WB, Decanini A, Mellgren A, Lowry AC, Goldberg SM, Madoff RD, et al. Does infliximab infusion impact results of operative treatment for Crohn's perianal fistulas? Dis Colon Rectum. 2007:50(11):1754-60.

39. Present $\mathrm{DH}$, Lichtiger $\mathrm{S}$. Efficacy of cyclosporine in treatment of fistula of Crohn's disease. Dig Dis Sci. 1994;39(2):374-80.

40. Hanauer SB, Smith MB. Rapid closure of Crohn's disease fistulas with continuous intravenous cyclosporin A. Am J Gastroenterol. 1993;88(5):646.

41. Lowry PW, Weaver AL, Tremaine WJ, Sandborn WJ. Combination therapy with oral tacrolimus (FK506) and azathioprine or 6-mercaptopurine for treatment-refractory Crohn's disease perianal fistulae. Inflamm Bowel Dis. 1999:5(4):239-45.

42. Targan SR, Hanauer SB, Van Deventer SJ, Mayer L, Present DH, Braakman $T$, et al. A short-term study of chimeric monoclonal antibody CA2 to tumor necrosis factor a for Crohn's disease. N Engl J Med. 1997; 337(15):1029-36.

43. Present DH, Rutgeerts $P$, Targan S, Hanauer SB, Mayer L, Van Hogezand R, et al. Infliximab for the treatment of fistulas in patients with Crohn's disease. N Engl J Med. 1999;340(18):1398-405.

44. García-Olmo D, García-Arranz M, Herreros D, Pascual I, Peiro C, RodríguezMontes JA. A phase I clinical trial of the treatment of Crohn's fistula by adipose mesenchymal stem cell transplantation. Dis Colon Rectum. 2005; 48(7):1416-23.

45. Garcia-Olmo D, Guadalajara H, Rubio-Perez I, Herreros MD, de la Quintana P, Garcia-Arranz M: Recurrent anal fistulae: limited surgery supported by stem cells. World J Gastroenterol: WJG 2015, 21(11):3330.

46. Lee WY, Park KJ, Cho YB, Yoon SN, Song KH, Kim DS, Jung SH, Kim M, Yoo HW, Kim I: Autologous adipose tissue-derived stem cells treatment demonstrated favorable and sustainable therapeutic effect for Crohn's fistula. Stem Cells 2013, 31(11):2575-2581. 
47. Van Koperen P, Safiruddin F, Bemelman W, Slors J. Outcome of surgical treatment for fistula in ano in Crohn's disease. Br J Surg. 2009;96(6): 675-9.

48. Shimizu H, Suzuki K, Watanabe M, Okamoto R. Stem cell-based therapy for inflammatory bowel disease. Intestinal Res. 2019;17(3):311.

\section{Publisher's Note}

Springer Nature remains neutral with regard to jurisdictional claims in published maps and institutional affiliations.

Ready to submit your research? Choose BMC and benefit from:

- fast, convenient online submission

- thorough peer review by experienced researchers in your field

- rapid publication on acceptance

- support for research data, including large and complex data types

- gold Open Access which fosters wider collaboration and increased citations

- maximum visibility for your research: over $100 \mathrm{M}$ website views per year

At BMC, research is always in progress.

Learn more biomedcentral.com/submissions 